\title{
Taman Seminari (Seminary Garden): Formation of the Character of Catholic Children
}

\author{
Adison Adrianus Sihombing ${ }^{1}$, Dian Nuri Ningtyas ${ }^{2}$ \\ \{sonadi2017@gmail.com¹, dian.nuriningtyas@gmail.com²
}

\begin{abstract}
Religious Literature, and Heritage Research and Development Agency and Training Ministry of Religion Jl. M.H. Thamrin No.6 Jakarta ${ }^{1}$, Research Center for Politics and Government, Department Politics and Government, Faculty of Social and Political

Science, Gadjah Mada University Yogyakarta ${ }^{2}$
\end{abstract}

\begin{abstract}
This article discusses operational license provision by the Directorate General of Catholic Community Guidance (Ditjen Bimas Katolik) for Catholic early educational system (PAUD) so-called Taman Seminari. This research developed the Index of Community Satisfaction, which put 79,2 for Ditjen Bimas Katolik. This score indicates the GOOD category, which shows that this institution provides good service in issuing the operational license for Taman Seminari. Regarding the index, The Catholic community responded positively to this government's policy. However, this research also revealed that the community is facing obstacles in obtaining the recommendation letter from the Catholic Church Hierarchy due to limited information from the side of Ditjen Bimas Katolik. This research concerns the early childhood education. Education is the foundation of human life, which creates the human mind and behavior. In Indonesia, the "first" level education in Early Childhood Education $(P A U D)$. As the first phase, PAUD becomes the most essential level to build the character of children. Taman Seminari School is the formal institution for early childhood Catholic religious education. Taman Seminari is established aiming for introducing and educating Catholic faith and values. Furthermore, it aims for the character building of the children to balance physics and spirituality. In doing so, Taman Seminari has been under the monitoring of the Directorate General of Catholic Community Guidance as part of the Ministry of Religion, as it was regulated by PMA No. 42 of 2016.
\end{abstract}

Keywords: Community Satisfaction Index, Early Childhood Education (PAUD), The Role of the State, Catholic Religious Education.

\section{Introduction}

The implementation of all levels of education is regulated in Regulation Number 20 of 2003 concerning the National Education System As for Early Childhood Education, it is regulated in article 28 and Permendikbud [11] (Regulation of the Ministry of Education and Culture) Number 137 of 2014 concerning National Standards for Early Childhood Education [15]. According to that regulation, early childhood education is an effort to foster the children starting from their birth until the age of six, which is carried out through educational designs to help 
children physical and spiritual growth and development in order that the children are ready to enter further level of education.

This definition implies that the substance of PAUD (Early Childhood Education) is to prepare all aspects of education for children such as that of motoric, that of cognitive, that of language, that of emotional as well as that of spiritual. According to Regulation of the Minister of Religion number 42 of 2016 in article 590 [16], one of the duties of the Directorate of Catholic Religious Education is to improve the quality of character education, religious education and Catholic religiosity [12] [14].

In response to this regulation, the Directorate General of Catholic Society Guidance thus, issued a Decree of the Director General of Catholic Society Guidance Number 23 of 2015, on the Technical Guidelines for Establishing a Seminarian Park stating that the Seminarian Park is a form of early childhood education unit on formal education track which organizes educational programs with the particularity of Catholic religion for children aged four to six years [6].

The Purpose of Taman Seminari Educational model is to introduce and to inculcate the valuesof the Catholic faith and to grow and develop Catholic children with the balance of both physical and spiritual competence. Taman Seminary is a public organization that provides educational services to Catholic society.

As a public organization, which is stipulated in the Regulation of the Minister of Administrative Reform and Bureaucratic Reform No. 14 of 2017 that in order to improve the quality of public services continuously, thus it is necessary to measure and evaluate the implementation of public services regularly [4], [17] .

Relevant with this, then the Directorate General of Catholic Society Guidance of the Ministry of Religious affairs conducted a regular survey concerning the service of granting an operational permit for the Taman Seminari.

\subsection{Problem}

Government Policy through the Directorate General of Catholic Society Guidance to establish Taman Seminari got a positive response from Catholic society because it is needed badly particularly for the Catholics for Christians living far from urban areas.

The problem is that the policy has not been officially socialized to all dioceses in Indonesia. As a result, not all the Catholic Churches hierarchy understand it. The problem is getting more complicated, as the program uses the term "seminary".

Therefore, the hierarchy is reluctant to provide a recommendation letter as one of the requirements for the establishment of a Taman Seminari school.

\subsection{Purpose of the study}

The research survey of society satisfaction with the service of granting operational license for the Taman Seminari of the Directorate General of Catholic Society Guidance of the Ministry of Religious Affairs has the aims as the following: 
1. To analyze the level of society satisfaction with the granting of the Operational Park permit.

2. To identify what services still need to be improved in the service of granting Taman Seminari operational license.

\subsection{Methodology}

This research uses a positivism approach with a mixed method with a Sequential Explanatory strategy [1] [3]. This strategy is implemented by collecting quantitative data and data analysis in the first phase followed by collecting and analyzing qualitative data in the second stage which is built on the basis of quantitative $\mathrm{p}$ results.

However, priority is given to quantitative data. The process of mixing data occurs when quantitative initial results inform the qualitative data collection process. Two types of data are separate, but interconnected. This strategy is used to explain and interpret quantitative results based on the results of qualitative data collection and analysis [3]. Quantitative data were collected through survey methods [9].

In this study a survey is conducted to get the facts from the existing phenomena and look for facts, both concerning social, economic, or political institutions of a group or a region [7], [8]. While qualitative data were collected by using the Focus Group Discussion (FGD) method, and in-depth interviews. In this study, the qualitative data were processed and elaborated in an executive summary as a basis for the basic of the policy recommendations.

\section{Research Findings}

\section{Service standards}

This component of public service standards is designed to provide the widest possible access to information to the public and minimize the possibility of maltreatment and irregularities in the procedures such as illegal payments. Service standard is determined through a Leadership Decree and contains 14 component elements in accordance with statutory regulations [13]. Public service providers are obliged to provide service announcements which are an expression of the ability of providers to full fill the service standards. This information must be published to the public through social media, websites or brochures

The rules regarding the Taman Seminari program / policy services are now stated in the Decree of the Director General of Catholic Community Guidance Number 23 of 2015 concerning the Technical Guidelines for the Establishment of a Seminary Park within the Catholic Directorate General Guidance [6]. There are no rules that contain a standard service for Submitting Operational Permit that is standardized and socialized to the community and stakeholders.

Based on field research it was found that there are at least 2 things that potentially hindering the process of obtaining the permit granting on Taman Seminari Operational 
Permit service, namely: (1) Low of knowledge and understanding on the technical procedures for establishing and submitting a Taman Seminari Operating Permit at the stakeholder level. This has the potential to slow down the process of getting recommendations both from the Church hierarchy and from the local Catholic Society Guidance. (2) The service standard has not been compiled as mandated by the regulations, so that the community and stakeholders are still experiencing confusion in the administration of the Taman Seminari Operational Permit.

\section{Socialization and publication of Taman Seminari}

Socialization and publication about Taman Seminari become important points to consider. Through this research, it was found that there was no harmonious communication among the Catholic Society Guidance, the Catholic Church Hierarchy, Ministry of Religious affairs officials in the low level area, and the society. This can be seen from the lack of knowledge and understanding of the Hierarchy about the Taman Seminari program and also the distrust to the Catholic society Guidance regarding Taman Seminari Program.

That phenomenon is very influential on the speed of getting recommendations for Institutions / Schools that wish to apply for a Taman Seminari Operational Permit, whereas the Operational Permit cannot be processed without a recommendation from the Church Hierarchy or local church officials. The same thing also happened at the level of Ministry of Religious affairs in the Region, in this case the Catholic society Guidance at the Provincial and District level. Socialization plays an important role because it contributes to public understanding of administrative policies and raises awareness of the role of decision makers [5] . The lack of knowledge and understanding on the Taman Seminari Program can be seen from the lack of confidence of the Educators when explaining this program to the public, or answering society questions about the Taman Seminari.

\section{Urgency of the existence of Taman Seminari}

The existence of Taman Seminari got a positive appreciation from parents and stakeholders. This is related to the lack of schools with characterize Catholic, especially in suburban areas. Taman Seminary is considered to be an oasis for the growth of the Catholic faith for children in that region.Other wise, Taman Seminary also got a positive appreciation because of the affordable education cost compared to the education cost in other Catholic Institutions.

This finding indicated that the establishment of Taman Seminari must consider the location, socio-economic conditions of the community, and competition with Catholic education foundations in the region. School Mapping is a normative approach to micro planning of school locations and it is also used to investigate and ensure an efficient and equitable distribution of resources both within and between school systems [2] . 


\section{Roadmap for organizational and management development}

Taman Seminary as an educational organization needs to have a road map for organizational development. Ideally, this road map should be set out in a Strategic Plan (Renstra) which starts from the highest level (Directorate General of Catholic Community Guidance) and then applied to the lowest level (Taman Seminari). Strategic planning is a systematic process for designing the future of educational institutions [10].

The Importance of Integrated Strategic Plan is to make every unit work to be able to draw up an annual work plan and to prepare a medium-term and long-term development plan according to the condition and situation of the organization. Integrated strategic plan also set the organization to be responsive to the external dynamics of the organization to achieve effective and efficient management. The organizational development road map will encourage organizations to develop continuously in all aspects, both of the level of organization and individually.

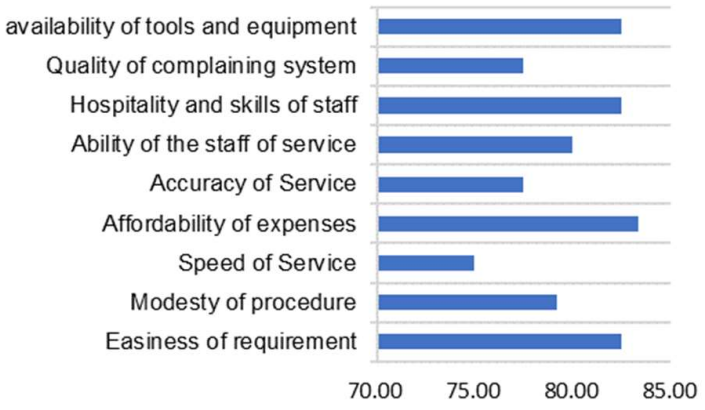

Fig. 1. Score of IKM in each element

\section{Society satisfaction level}

Research shows that the service for granting The Taman Seminari Operational Permit by the Directorate General of Catholic society Guidance reaches the GOOD category. This research developed the Index of Community Satisfaction, which put 79,2 for Ditjen Bimas Katolik, which shows that this institution provides good service in issuing the operational license for Taman Seminari . These criteria are based on the Regulation of the Minister of Administrative Reform and Bureaucratic Reform No. 14 of 2017 concerning Guidelines for the Preparation of society Satisfaction Surveys.

The all elements are in the GOOD category with score between 75 to 83.33 . The cost accessibility is the element which is considered to contribute the highest score, while the element that contributes the lowest score is the speed of service. 


\section{Recomendations}

In order to encourage the achievement of continuous service improvement, based on the results of data analysis in the study of "Survey of Society Satisfaction to the Service of Granting of Operational License for Taman Seminari at the Directorate General of Catholic Community Guidance, Ministry of Religious affairs in 2019", thus, the policy agenda for improving service granting of Taman Seminari Operational Licensing Services by the Directorate General of Catholic Society Guidance are as follows:

1. The Directorate General of Catholic society Guidance should conduct socialization to the Catholic Church Hierarchy continuously to introduce the Taman Seminari program and provide a comprehensive explanation in order that the program is known and gets support from the Catholic Church Hierarchy.

2. To conduct comprehensive socialization to officials under the Directorate General of the Catholic Society Guidance in the region (Educators of Society, organizers, instructors, and supervisors).

3. To set the service standard in Granting Taman Seminari Operational Permits and to disseminate information to all work units relating to the management of Taman Seminari Operational Permits.

4. To publish Technical Guidance Handbook on granting a Taman Seminari Operational Permit and stipulate SOP on the management of an Operating Permit in order to have uniformity of procedure in the management of a Taman Seminari Operating Permit.

5. To arrange a road map for organizational development and management for Taman Seminari schools that have obtained an Operational License.

6. To digitize permit application (online).

\section{References}

[1] Arikunto, (2006). Prosedur Penelitian Suatu Pendekatan Praktik. Revision Ed VI. PT Rineka Cipta: Jakarta

[2] Caillods, F. (1983). Module I: School mapping and micro-planning concepts and processes. In F. Caillods, J. Casselli, T. N. Châu \& G. Porte (Eds.), Training materials in educational planning, administration and facilities: School mapping and micro-planning in education. Paris, France:IIEP/UNESCO

[3] Creswell, John W. Research Design Pendekatan Kualitatif, Kuantitatif, dan Mixed, terj. Achmad Fawaid. Yogyakarta: Pustaka Pelajar, 2010

[4] Denhardt, Janet V. and Denhardt, Robert B, (2003). The New Public Service: Serving, not Steering. M.E. Sharpe, Inc.New York.

[5] Édes B.W. (2000). The role of government information officers. Journal of Government Information, vol. 27 , n. 4 , pp. $455-469$ 
[6] Kementeria Agama Republik Indonesia. (2015). Keputusan Direktur Jenderal Bimbingan Masyarakat Katolik No 23 Tahun 2015 Tentang Petunjuk Teknis Pendirian Taman Seminari di Lingkungan Direktorat Jenderal Bimbingan Masyarakat Katolik. Direktorat Jendral Bimbingan Masyarakat Katolik: Jakarta

[7] M. Nazir. (1983). Metode Penelitian. Ghalia Indonesia: Jakarta

[8] Prasetya Irawan. (2006). Penelitian Kualitatif dan Kuantitatif untukI lmu-Ilmu Sosial. FISIP UI: Depok

[9] Sarwono, Jonathan, (2016). Metode Penelitian Kuantitatif dan Kualitatif. PT. Grahallmu: Yogyakarta [10] Reeves D . (2008). Leading to change/making strategic planning work. Educational Leadership 65: 86-87

[11] Republik Indonesia. (2003). Undang-Undang Republik Indonesia Nomor 20 Tahun 2003 tentang Sistem Pendidikan Nasional. Sekretariat Negara: Jakarta

[12] Republik Indonesia. (2007). Peraturan Pemerintan Nomor 55 Tahun 2007 Tentang Pendidikan Agama dan Pendidikan Keagamaan. Sekretariat Negara: Jakarta

[13] Republik Indonesia. (2009). Undang-Undang Republik Indonesia Nomor 25 Tahun 2009 tentang Pelayanan Publik. Sekretariat Negara: Jakarta

[14] Republik Indonesia. (2013). Peraturan Presiden No 60 Tahun 2013 Tentang Pengembangan Anak Usia Dini Holistik-Integratif. Sekretariat Negara: Jakarta

[15] Republik Indonesia. (2014). Peraturan Menteri Pendidikan Nasional No 137 Tahun 2014 Tentang Standar Pendidikan Anak Usia Dini. Sekretariat Negara: Jakarta

[16] Republik Indonesia. (2016). Peraturan Menteri Agama No.42 Tahun 2016 Tentang Organisasi dan Tata Kerja Kementerian Agama. Sekretariat Negara: Jakarta

[17] Republik Indonesia. (2017). Peraturan Mentri Pendayangunaan Aparatur Negara dan Reformasi Birokrasi Nomor 14 Tahun 2017 tentang Pedoman Penyusunan Survei Kepuasan Masyarakat. Sekretariat Negara: Jakarta 